\title{
Cardiopulmonary exercise testing in cardiovascular rehabilitation of post-myocardial infarction patients
}

\author{
Mihai Roca',2, Magda Mitu², Radu-Sebastian Gavril ${ }^{1,2}$, Maria-Magdalena Leon Constantin ${ }^{1,2}$, Iulia-Cristina Roca ${ }^{1,3}$,
} Florin Mitu',

\begin{abstract}
Cardiovascular rehabilitation represents a very important measure in post myocardial infarction patients for both, improving their quality of life and preventing other acute cardiovascular events. It is important to accurately assess functional capacity of patients after acute coronary events, in order to optimize the results of cardiac rehabilitation program. Cardiopulmonary exercise testing (CPET) represents the gold standard in functional capacity assessment. We present 3 clinical cases of post STEMI patients, with coronary revascularization interventions, addressed to cardiovascular rehabilitation. They underwent CPET evaluation at baseline and during rehabilitation program. This method proved important utility for individualization of cardiovascular rehabilitation program, as well as for monitoring the long term evolution after myocardial infarction.
\end{abstract}

Keywords: cardiopulmonary exercise testing, myocardial infarction, cardiac rehabilitation.

Rezumat: Recuperarea cardiovasculară reprezintă o măsură importantă la pacienții post-infarct miocardic acut, atât din punct de vedere al efectelor de îmbunătățire a calității vieții, cât și pentru prevenția apariției altor evenimente cardiovasculare. Pentru optimizarea rezultatelor programului de recuperare cardiovasculară este importantă evaluarea riguroasă a capacității funcționale a pacienților după evenimentul coronarian acut. Testarea cardiopulmonară de efort (CPET) reprezintă standardul de aur în evaluarea capacității funcționale. Prezentăm trei cazuri clinice ale unor pacienți cu STEMI și intervenții de revascularizare coronariană, la care s-a indicat recuperarea cardiovasculară. La acești pacienți s-a realizat evaluarea prin CPET atât la inițiere cât și pe parcursul programului de reabilitare cardiovasculară. Metoda s-a dovedit utilă pentru individualizarea programului de recuperare cardiovasculară dar și pentru monitorizarea evoluției pe termen lung la pacienții cu infarct miocardic.

Cuvinte cheie: testare cardiopulmonară de efort, infarct miocardic, recuperare cardiovasculară.

\section{INTRODUCTION}

Although myocardial infarction remains a common event in patients with cumulative cardiovascular risk factors, the increasing accessibility to modern therapeutic resources of myocardial revascularization, determined a significant improvement of surviving'. However, patients surviving an acute coronary event need to be included in a cardiovascular rehabilitation (CR) program, to restore their functional capacity and quality of life, to control risk factors and to prevent the recurrence of acute cardiovascular events ${ }^{2}$.

\footnotetext{
' "Grigore T. Popa” University of Medicine and Pharmacy, lasi, Romania

${ }^{2}$ Clinical Rehabilitation Hospital, lasi, Romania

${ }^{3}$ „Sf. Spiridon” Emergency Clinical Hospital, lasi, Romania
}

It is important to individualize the parameters of aerobic exercise training within CR program, considering clinical and functional particularities of the patient.

Currently, the gold standard in functional capacity assessment is cardiopulmonary exercise testing (CPET), recommended by clinical guidelines for CR, in order to maximize benefits and to minimize risks associated to aerobic exercise training ${ }^{3-7}$. In addition, CPET represents the most rigorous assessment of the effectiveness of $C R$ program ${ }^{8,9}$. 
In this paper we present three clinical cases to exemplify CPET using in CR programs, highlighting the benefits obtained, according to the clinical particularities of each case.

\section{CASE SERIES}

\section{Case I}

A 48-year-old male was known for ten years with essential hypertension, type 2 diabetes mellitus under oral therapy and mixed dyslipidemia. The patient was admitted to Clinical Recovery Hospital lasi, for phase II CR, two month after an anterior STEMI, treated by

\begin{tabular}{|l|c|c|}
\hline \multicolumn{3}{|l|}{ Table I. Case I - CPET parameters } \\
\hline Time after STEMI (month) & 2 & 8 \\
\hline Workload (Watt) [\% of predicted] & $\mathrm{I} 42[70 \%]$ & $\mathrm{I77}[88 \%]$ \\
\hline Peak $\mathrm{VO}_{2}$ (ml/minute) & 1517 & 1985 \\
\hline Peak $\mathrm{VO}_{2} \%$ of predicted & 64 & 85 \\
\hline Ventilatory threshold (ml/kg/minute) & 20 & 27.9 \\
\hline Respiratory Exchange Ratio & 1.01 & 1.14 \\
\hline$\Delta \mathrm{VO}_{2} / \Delta \mathrm{WR}(\mathrm{ml} /$ minute $* \mathrm{~W})$ & 9.02 & 9.02 \\
\hline $\mathrm{VE} / \mathrm{VCO}{ }_{2}$ slope & 27 & 27.6 \\
\hline Maximum heart rate (bpm) [\% of predicted] & $\mathrm{I} 37[80 \%]$ & $140[82 \%]$ \\
\hline Maximum $\mathrm{O}_{2}$ pulse \% of predicted & 86 & 100 \\
\hline Maximum blood pressure (mmHg) & $160 / 100$ & $190 / 100$ \\
\hline Target heart rate for CR program & 110 & 115 \\
\hline
\end{tabular}

percutaneous coronary intervention $(\mathrm{PCl})$, with drug eluting stent implantation on the left anterior descending artery. At the admission, the patient presented slight limitation during ordinary activity. Echocardiography revealed a left ventricular apical hypokinesia and a left ventricle ejection fraction limited to $50 \%$.

Functional capacity was assessed by CPET, before initiating $\mathrm{CR}$. The most important CPET parameters were: maximum oxygen consumption (peak $\mathrm{VO}_{2}$ ), maximum workload (WR [Watt]), ventilatory (anaerobic) threshold (AT), oxygen $\left(\mathrm{O}_{2}\right)$ pulse, relation between $\mathrm{VO}_{2}$ and workload $\left(\Delta \mathrm{VO}_{2} / \Delta \mathrm{WR}\right.$ slope), relation between minute ventilation (VE) and carbon dioxide production ( $\mathrm{VE} / \mathrm{VCO}_{2}$ slope), maximum heart rate, maximum blood pressure (Figure I, 2, 3, 4).

CPET revealed a pattern of cardiac moderate functional limitation (peak $\mathrm{VO}_{2} 64 \%$ of predicted value) and determined a target heart rate of 110 beats per minute (bpm), for aerobic exercise training during CR program. The main results are presented in Table I (two month after the STEMI). The patient continued a long term ambulatory CR program. After 6 month, CPET assessment revealed significant improvement of the functional capacity (Table I - 8 month after the STEMI).

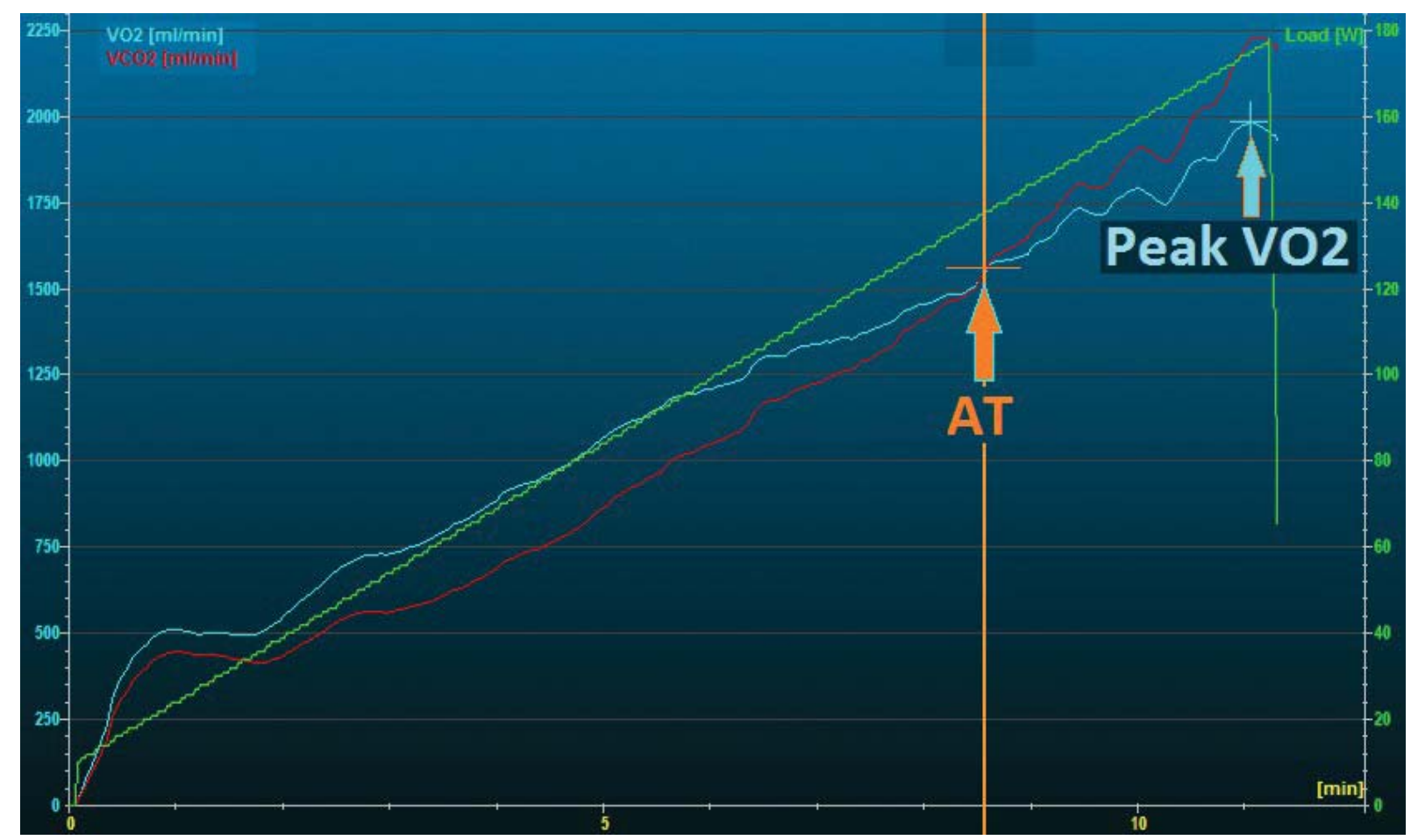

Figure I. Peak $\mathrm{VO}_{2}$ detection (case I): maximum oxygen consumption recorded during progressive intensity exercise; ventilatory (anaerobic) threshold (AT) detection: During progressive increasing of exercise intensity, at a given workload, oxygen supply to the muscle does not meet the oxygen requirements. This imbalance determines the necessity of anaerobic glycolysis in order to provide muscle energy, resulting in lactic acid production. Conversion of lactic acid to lactate, results in an excess of $\mathrm{CO}_{2}$ production, which is revealed on graphical representation of trend for VO $\mathrm{O}_{2}$ and $\mathrm{VCO}$ (anaerobic threshold). 


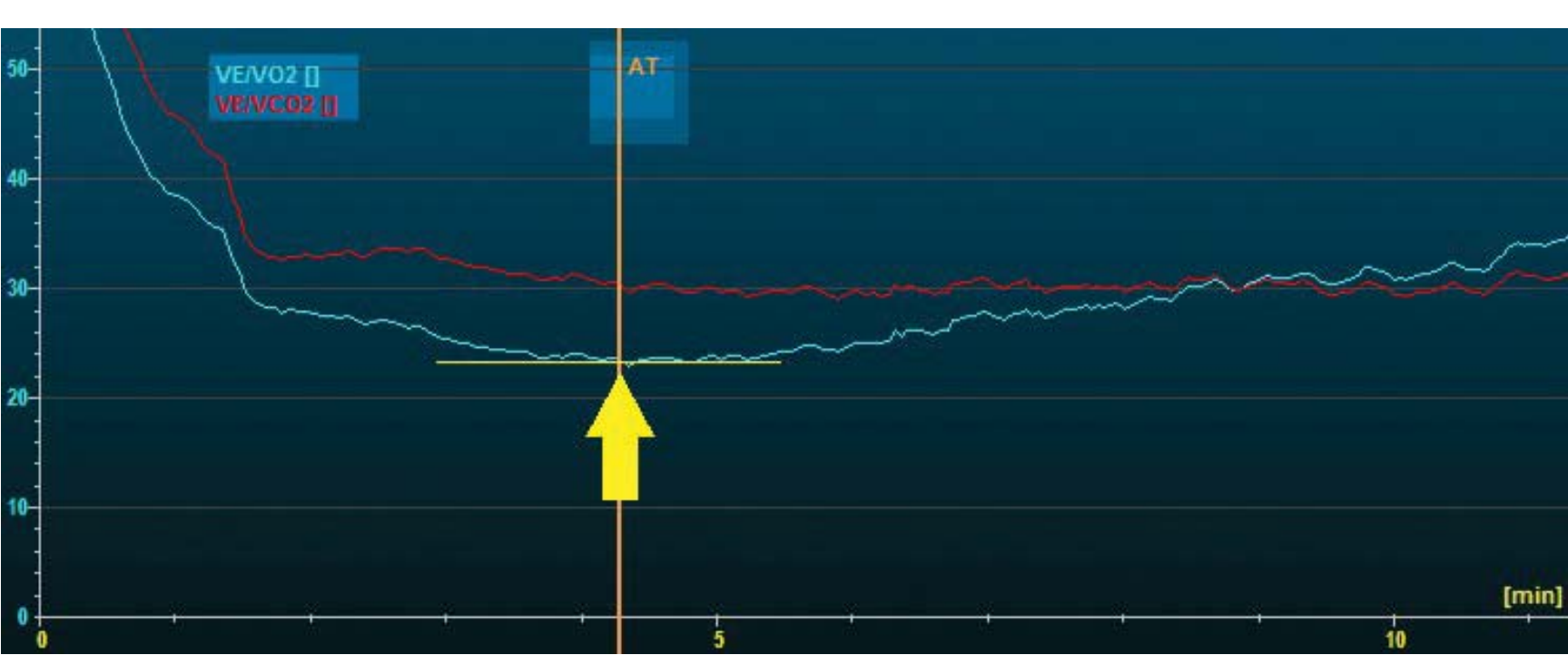

Figure 2. Ventilatory threshold detection applying ventilatory equivalents method (case I):At the anaerobic threshold, a physiological increase in ventilation (VE) simultaneously appears, to eliminate the excess $\mathrm{CO}_{2}$ (ventilatory threshold). It is the point at which, an increase of the ventilatory equivalent for oxygen $\left(\mathrm{VE} / \mathrm{VO}_{2}\right)$ occurs, without an increase of ventilatory equivalent for carbon dioxide $\left(\mathrm{VE} / \mathrm{VCO}_{2}\right)$.

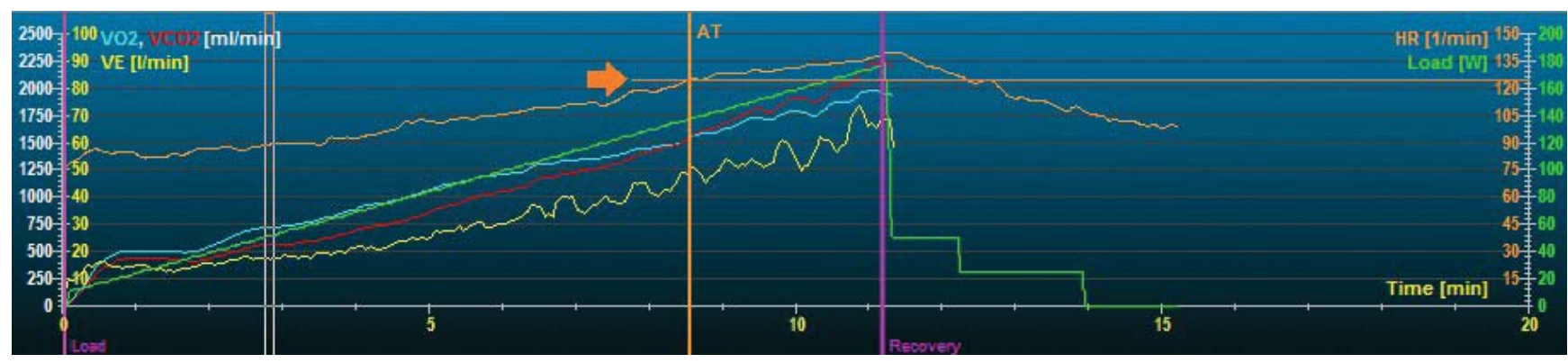

Figure 3. Target heart rate detection for aerobic training within cardiovascular rehabilitation (case I):Ventilatory threshold marks the upper limit of light to moderate - intensity effort domain. Light to moderate-intensity training is the most indicated for cardiovascular rehabilitation of cardiac patients with a markedly reduced exercise capacity, for those with high exercise-related risk, or recent hemodynamic decompensation, including patients after myocardial infarction ${ }^{3}$. The heart rate corresponding to ventilatory threshold represents the target heart rate during aerobic exercise training: II5 bpm for case I.

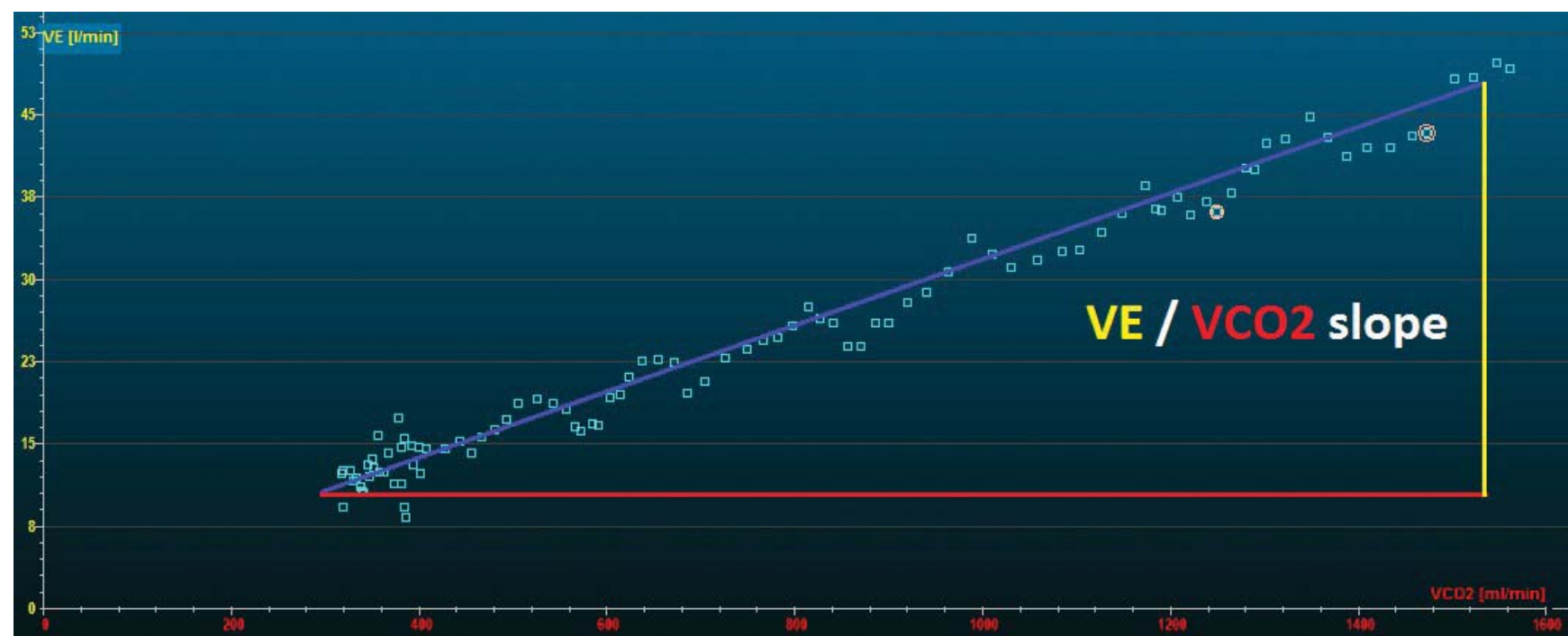

Figure 4. $\mathrm{VE} / \mathrm{VCO}_{2}$ slope calculation (case I): This parameter represents an index of ventilator efficiency, with a normal threshold $<30$, which can be exceeded in heart failure or pulmonary hypertension. This parameter is not influenced by age or sex and presents high test-retest reliability, being uninfluenced by exercise testing protocol 4 . For case I,VE/VCO2 slope presented a normal value of 27. 


\begin{tabular}{|c|c|c|c|c|}
\hline Time after STEMI (month) & 1 & 3 & 7 & 22 \\
\hline Workload (Watt) [\% of predicted] & $96[45 \%]$ & $105[49 \%]$ & $123[5 \mid \%]$ & $140[57 \%]$ \\
\hline Peak $\mathrm{VO}_{2}(\mathrm{ml} /$ minute $)$ & 1323 & 1384 & 1508 & 1470 \\
\hline Peak $\mathrm{VO}_{2} \%$ of predicted & 45 & 47 & 52 & 51 \\
\hline Ventilatory threshold ( $\mathrm{ml} / \mathrm{kg} /$ minute) & 15.1 & 15.8 & 13.8 & 9.6 \\
\hline Maximum heart rate (bpm) [\% of predicted] & $113[6 \mid \%]$ & $120[65 \%]$ & $142[77 \%]$ & $127[69 \%]$ \\
\hline Maximum $\mathrm{O}_{2}$ pulse [\% of predicted] & 74 & 74 & 70 & 73 \\
\hline$\Delta \mathrm{VO}_{2} / \Delta \mathrm{WR}\left(\mathrm{ml} /\right.$ minute $\left.^{*} \mathrm{~W}\right)$ & 11.9 & 11.89 & 7.26 & 7.26 \\
\hline VE/VCO ${ }_{2}$ slope & 23.8 & 26.2 & 22.5 & 23.6 \\
\hline Maximum blood pressure $(\mathrm{mmHg})$ & $140 / 90$ & $170 / 110$ & $180 / 110$ & $180 / 100$ \\
\hline Target heart rate for CR program & 85 & 105 & 105 & 80 \\
\hline
\end{tabular}

\section{Case 2}

A 35-year-old male, smoker, overweight, known with dyslipidemia, was admitted to our clinic, for phase II $\mathrm{CR}$, one month after an anterior STEMI, treated by $\mathrm{PCl}$. Echocardiographic examination at hospital admission revealed a left ventricular apical hypokinesia and a left ventricle ejection fraction of $50-60 \%$.

The results of CPET were consistent with a cardiac pattern of moderate-severe functional limitation: decreased peak $\mathrm{VO}_{2}$ and ventilatory threshold; decreased maximum $\mathrm{O}_{2}$ pulse; normal ventilatory reserve (Table 2 - one month after the STEMI).

The patient initiated $C R$ in our clinic, continuing an ambulatory CR program. Two month later, a second CPET revealed slight improvement of the most important parameters (Table 2 - CPET parameters at 3 month after the STEMI). A third CPET assessment was done four month later, proving significant improvements of workload, maximum oxygen consumption and maximum heart rate. However, the results revealed a significant negative trend, apparently paradoxical, for two key parameters: ventilatory threshold and maximum oxygen pulse (Table 2 - CPET parameters at 7 month after the STEMI). The next CPET assessment, done at 15 month, revealed important changes in functional capacity. Although work rate level seems to improve, peak $\mathrm{VO}_{2}$ had a slight decrease, while ventilatory threshold and maximum heart rate presented a significant negative trend (Table 2 - CPET parameters at 22 month after the STEMI).

Inline with CPET changes, echocardiography revealed left ventricular apical hypokinesia, involving interventricular septum and left ventricle lateral wall, suggesting left ventricle apical aneurysm. Furthermore, left ventricle ejection fraction decreased to 40 $45 \%$, compared to previous echographic exam.

\section{Case 3}

A 56-year-old male, smoker, was known with chronic coronary artery disease (left anterior descending artery and left main trunk lesions), hypertension, mixed dyslipidemia, grade I obesity. The patient was admitted in our clinic, to be included in phase II CR program, five month after anteroseptal STEMI and coronary artery bypass grafting (CABG). At the admission, the patient presented a moderate limitation during ordinary activity. Echocardiographic examination revealed left ventricular regional wall motion abnormality with ejection fraction of $50 \%$.

Maximum oxygen consumption, and ventilatory threshold assessed at CPET, corresponded to a moderate-severe alteration of functional capacity, while $\mathrm{O}_{2}$ pulse was $76 \%$ of predicted maximum (Table $3-5$ month after the STEMI). The results of CPET presented above were consistent with a cardiac pattern of moderate-severe functional limitation.

The patient initiated $C R$ in our clinic, continuing an ambulatory $C R$ program. One year later, the results of CPET proved significant improvements of functional capacity, from moderate-severe alteration to mildmoderate alteration (Table 3 - CPET parameters at

\begin{tabular}{|c|c|c|}
\hline Time after STEMI (month) & 5 & 17 \\
\hline Workload (Watt) [\% of predicted] & $126[63 \%]$ & $117[58 \%]$ \\
\hline Peak $\mathrm{VO}_{2}(\mathrm{ml} / \mathrm{minute})$ & 1270 & 1585 \\
\hline Peak $\mathrm{VO}_{2} \%$ of predicted & 46 & 58 \\
\hline Ventilatory threshold (ml/kg/minute) & 8.06 & 13.2 \\
\hline Maximum heart rate (bpm) [\% of predicted] & $105[64 \%]$ & $104[63 \%]$ \\
\hline Maximum $\mathrm{O}_{2}$ pulse $\%$ of predicted & 76 & 100 \\
\hline$\Delta \mathrm{VO}_{2} / \Delta \mathrm{WR}(\mathrm{ml} /$ minute $* \mathrm{~W})$ & 6.97 & 6.54 \\
\hline VE/VCO ${ }_{2}$ slope & 21.8 & 21.8 \\
\hline Maximum blood pressure $(\mathrm{mmHg})$ & $210 / 100$ & $190 / 100$ \\
\hline Target heart rate for CR program & 90 & 95 \\
\hline
\end{tabular}


17 month after the STEMI). Echocardiography revealed left ventricular segmental hypokinesia, with preserved ejection fraction.

\section{DISCUSSION}

We presented 3 clinical cases of post STEMI patients addressed to CR. The first two cases were young males, successfully treated by $\mathrm{PCl}$.

For all three cases, CR program was initiated with 20 minutes sessions of mild, progressively increased to moderate intensity, continuous aerobic exercise training, aiming the target heart rate individually determined by CPET. This test allowed the optimal setting of intensity for exercise training. Training session was preceded and followed by warm-up and cooling down 10 minutes periods, respectively.

First case presented higher baseline aerobic capacity and $\mathrm{O}_{2}$ pulse, and a very good long term improvement of these parameters during CR program. However, the second case presented significant reductions of baseline levels for aerobic capacity and $\mathrm{O}_{2}$ pulse, and a failure in improvement of these parameters during long term evolution, despite carrying out CR program.

This lack of efficiency of $C R$ in second case was concordant with echocardiographic aspects of unfavorable myocardial remodeling with left ventricle apical aneurysm and ejection fraction decreasing. However, alterations of maximum $\mathrm{O}_{2}$ pulse during CPET, preceded echographic changes. Our results are inline with those of some clinical studies which proved that selected CPET parameters (as peak $\mathrm{VO}_{2}$, ventilatory threshold, $\mathrm{O}_{2}$ pulse) seem to be highly sensitive to changes in cardiac function following $\mathrm{PCl}$, significantly better than conventional stress ECG ${ }^{10,11}$.

In the second clinical case, ventilatory threshold was the best predictor of unfavorable evolution, presenting the earliest and the most significant negative trend, which preceded echocardiographic alterations.

The third clinical case represents a patient addressed to $C R$ post STEMI and CABG. Unlike second clinical case, the long term evolution was favorable, with significant functional improvement during $C R$, despite baseline low values of peak $\mathrm{VO}_{2}$, ventilatory threshold and $\mathrm{O}_{2}$ pulse. These parameters presented important CR related improvement. However, there is a lack of clinical researches referring the predictors of long term cardiac changes in patients with STEMI and CABG following $C R^{12}$.

Considering the results previously obtained in other clinical studies, a lower baseline aerobic capacity and a more reduced baseline ejection fraction, represent predictors of a higher functional capacity improvement after exercise based $\mathrm{CR}$, among myocardial infarction survivals, irrespective of the management modality for acute coronary event ${ }^{13,14}$.

\section{CONCLUSIONS}

CPET greatly enhance the evaluation of patients addressed to cardiovascular rehabilitation. This test is essential for optimizing the parameters of aerobic exercise training, in order to maximize benefits and to minimize the risk for CR program. Furthermore, CPET repeatedly done, during and after CR program, facilitates the objectification of functional cardiovascular benefits, within this program, and allows a long term prognostic assessment. Prognostic value of CPET may exceed the evaluation methods in resting conditions, such as cardiac echography and ECG. However, the role of CPET in CR is not completely defined, new clinical studies being necessary.

\section{Conflict of interest: none declared.}

\section{References}

I. Neumann FJ, Sousa-Uva M, Ahlsson A, Alfonso F, Banning AP, Benedetto U, Byrne RA, Collet JP, Falk V, Head SJ, Jüni P, Kastrati A, Koller A, Kristensen SD, Niebauer J, Richter DJ, Seferovic PM, Sibbing D, Stefanini GG, Windecker S, Yadav R, Zembala MO; ESC Scientific Document Group. 2018 ESC/EACTS Guidelines on myocardial revascularization. Eur Heart J 2019;40(2):87-165.

2. Corrà U, Mendes M, Piepoli M, Saner H. Future perspectives in cardiac rehabilitation: a new European Association for Cardiovascular Prevention and Rehabilitation Position Paper on 'secondary prevention through cardiac rehabilitation'. Eur J Cardiovasc Prev Rehabil 2007; | 4(6):723-5.

3. Varga A, Tilea I, Palermo P. Cardiopulmonary exercise test in clinical practice, evaluation of myocardial ischemia. Romanian Journal of Cardiology 2019;29(3):390-398.

4. Caloian B, Pop D, Gușetu G, Zdrenghea D. The role of cardiopulmonary exercise testing in the initial evaluation of patients wearing intracardiac devices submitted to cardiac rehabilitation. Balneo Research Journal 2017;8(4):206-2II.

5. Lollgen H, Leyk D. Exercise testing in sports medicine. Dtsch Arztebl Int 2018; I I5:409-16.

6. Mezzani A. Cardiopulmonary exercise testing: basics of methodology and measurements. Ann Am Thorac Soc 2017; I4:S3-II.

7. Gherasim D. Rolul testului de efort în programele de recuperare. În: Recuperare și prevenție cardiovasculară. Editor: Zdrenghea D. Editura Clusium, Cluj-Napoca, 2008, 64-92.

8. Mezzani A, Hamm LF, Jones AM, McBride PE, Moholdt T, Stone JA, Urhausen A, Williams MA. Aerobic exercise intensity assessment and prescription in cardiac rehabilitation: a joint position statement of the European Association for Cardiovascular Prevention and Rehabilitation, the American Association of Cardiovascular and Pulmonary Rehabilitation and the Canadian Association of Cardiac Rehabilitation. Eur J Prev Cardiol 2013;20(3):442-67.

9. Balady GJ, Arena R, Sietsema K, Myers J, Coke L, Fletcher GF, Forman D, Franklin B, Guazzi M, Gulati M, Keteyian SJ, Lavie CJ, Macko R, Mancini D, Milani RV. Clinician's Guide to cardiopulmonary exercise testing in adults: a scientific statement from the American Heart Association. Circulation 2010;122(2):191-225. 
10. Inbar O, Yamin C, Bar-On I, Nice S, David D. Effects of percutaneous transluminal coronary angioplasty on cardiopulmonary responses during exercise. J Sports Med Phys Fitness 2008;48(2):235-45.

II. Chaudhry S, Arena R, Bhatt DL, Verma S, Kumar N. A practical clinical approach to utilize cardiopulmonary exercise testing in the evaluation and management of coronary artery disease: a primer for cardiologists. Curr Opin Cardiol 2018; 33(2): I68-I77.

12. Suzuki Y, Ito K, Yamamoto K, Fukui N, Yanagi H, Kitagaki K, Konishi $\mathrm{H}$, Arakawa T, Nakanishi M, Goto Y. Predictors of improvements in exercise capacity during cardiac rehabilitation in the recovery phase after coronary artery bypass graft surgery versus acute myocardial infarction. Heart Vessels 2018;33(4):358-366.
13. Aguiar Rosa S, Abreu A, Marques Soares R, Rio P, Filipe C, Rodrigues I, Monteiro A, Soares C, Ferreira V, Silva S, Alves S, Cruz Ferreira R. Cardiac rehabilitation after acute coronary syndrome: Do all patients derive the same benefit? Rev Port Cardiol 2017;36(3):169176.

14. Vilela EM, Ladeiras-Lopes R, Ruivo C, Torres S, Braga J, Fonseca M, Ribeiro J, Primo J, Fontes-Carvalho R, Campos L, Miranda F, Nunes JPL, Gama V, Teixeira M, Braga P. Different outcomes of a cardiac rehabilitation programme in functional parameters among myocardial infarction survivors according to ejection fraction. Neth Heart J 2019;27(7-8):347-353 